Table 2. Final sand $\mathrm{pH}^{\mathrm{z}, \mathrm{y}}$

\begin{tabular}{ccc}
\hline \hline $\mathrm{NH}_{4}^{+}: \mathrm{NO}_{3}^{-}$ & $\mathrm{pH}_{\mathrm{w}}^{\mathrm{x}}$ & \multicolumn{1}{c}{$\mathrm{pH}_{\mathrm{b}}$} \\
\hline $1: 0$ & $4.1 \mathrm{c}$ & $8.14 \mathrm{c}$ \\
$3: 1$ & $4.2 \mathrm{c}$ & $8.31 \mathrm{a}$ \\
$1: 1$ & $4.6 \mathrm{c}$ & $8: 23 \mathrm{~b}$ \\
$1: 3$ & $5.7 \mathrm{~b}$ & $8.27 \mathrm{ab}$ \\
$0: 1$ & $6.6 \mathrm{a}$ & $8.28 \mathrm{ab}$ \\
LSD $(0.05)$ & 0.76 & 0.07 \\
\hline
\end{tabular}

${ }^{2}$ Data are the means of five observations. ${ }^{\mathrm{y}_{\mathrm{pH}}} \mathrm{H}_{\mathrm{w}}=$ water $\mathrm{pH} ; \mathrm{pH}_{\mathrm{b}}=$ buffer $\mathrm{pH}$.

$\times$ Beginning $\mathrm{pH}_{\mathrm{w} .}=5.4$.

drops below 4.5 (Barker and Mills, 1980). Darrow (1939) found $\mathrm{NH}_{4}^{+}$fertilized Kentucky bluegrass (Poa pratensis) produced more shoots, roots, and rhizomes at $\mathrm{pH} 6.5$ than at 5.5 or 4.5 , while $\mathrm{NO}_{3}^{-}$-treated plants grew equally well at all three $\mathrm{pH}$ levels.

Since soil microbial activity promotes nitrification more rapidly than sand (Quastel and Scholefield, 1951), previous research (Eggens and Wright, 1985) indicating that high $\mathrm{NH}_{\ddagger}^{+}$atios decreased root growth may be viewed as misleading, since most putting greens do not consist of $100 \%$ sand. However, our results indicate $\mathrm{N}$ form can significantly influence initial root length and weight and root : shoot ratio of sodded creeping bentgrass on sandy loam soils. Bentgrass sod fertilized wit $\mathbb{N H}_{4}^{+}-$roduced less root growth and darker green shoots. The ratio of 1:3 produced the most favorable root weights. Ratios of $1: 1$ and $3: 1$ produced about equally favorable root lengths. The similarity of our results with that of Eggens and Wright (1985) suggest the effect of $\mathrm{N}$ form on root growth occurs over a wide range of circumstances; some of the differences in the two studies were the plant densities (sod vs. single plants), soil type (sandy loam vs. sand), total applied $\mathrm{N}$ (265 vs. $3472 \mathrm{~kg} \mathrm{~N} / \mathrm{ha}$ ), soil $\mathrm{pH}$, and mowing height. Previously $\mathrm{NH}_{4}^{+}$: $\mathrm{NO}_{3}^{-}$ratio was reported to have no effect on bentgrass root or shoot growth under field conditions (Markland and Roberts, 1969; Mazur and Hughes, 1976); however, these studies were conducted on established turf. The results reported here suggest further investigation should be made dealing with the use of $\mathrm{NO}_{3}^{-}$-Nn greens established with bentgrass sod.

\section{Literature Cited}

Adams, F. and C.E. Evens. 1962. A rapid method for measuring lime requirement of red-yellow podzolic soils. Soil Sci. Soc. Amer. Proc. 26:355-357.

Barker, A.V. and H.A. Mills. 1980. Ammonium and nitrate nutrition of horticultural crops. Hort. Rev. 2:395-425.

Bowman, D.C. 1988. Uptake and assimilation of $\mathrm{NH}_{4}^{+}$and $\mathrm{NO}_{3}^{-}$by nitrogen deficient perennial ryegrass turf: Plant Physiol. 88:1303-1309.

Darrow, R.A. 1939. Effects of soil temperature, $\mathrm{pH}$, and nitrogen nutrition on the development of Poa pratensis. Bot. Gaz. 101:109-128.

Eggens, J.L. and C.P.M. Wright. 1985. Nitrogen effects on monostands and polystands of annual bluegrass and creeping bentgrass. HortScience 20(1):109-110.

Harrison, C.M. 1933. Responses of Kentucky bluegrass to variations in temperature, light, cutting and fertilizing. Plant Physiol. 9:83-106.
Issac, R.A. and W.C. Johnson. 1976. Determination of total nitrogen in plant tissue. J. Assn. Offic. Anal. Chem. 59:98-100.

Markland, F.E. and E.C. Roberts, 1969. Influence of nitrogen fertilizer on Washington creeping bentgrass, Agrostis palustris Huds. I. Growth and mineral composition. Agron. J. 61:698-700.

Maynard, D.N. and A.V. Barker. 1970. Nutriculture: A guide to the soilless culture of plants. Coop. Ext. Serv. Publ. 41, Univ. of Massachusetts.

Mazur, A.R. and T.D. Hughes. 1976. Chemical composition and qualitv of Penncross creeping bentgrass as affected by ammonium, nitrate,' and several fungicides. Agron. J. 68:721-723.

Munsell Color Charts for Plant Tissues. 2nd ed. 1977. Macbeth, Baltimore.

Nittler, L.W. and T.J. Kenny. 1976. Effect of ammonium to nitrate ratio on growth and anthocyanin development of perennial ryegrass cultivars. Agron. J. 68:680-683.

Quastel, J.H. and P.G. Scholefield. 1951. Biochemistry of nitrification in soil. Bacterial. Rev. 15:1-53.

HOR TSCIENCE 25(8):933-935. 1990.

\title{
Apple Tree Vigor Influences Flowering and Dry Weight after Paclobutrazol Application
}

\author{
Laura J. Lehman', Eric Young, and C.R. Unrath \\ Department of Horticultural Science, North Carolina State University, \\ Raleigh, NC 276957609
}

Additional index words. growth regulator, Malus domestica, PP333

Abstract. Spur-type or nonspur 'Delicious' apple scions on either Malus domestica Borkh. (seedling) or M.26 rootstocks received paclobutrazol foliar sprays in one or two 'consecutive years or a soil drench in the year of planting. For each scion, total shoot, root shank, and tree dry weights measured in the 3rd year after planting were suppressed by all treatments. Trees on M.26 put less dry weight into rootstock wood after foliar sprays, but trees on seedling were not similarly affected. No treatment influenced fibrous root dry weight of the spur-type scion on seedling, while all treatments suppressed dry-weight gain of the same scion on M.26. All trees had higher root : shoot ratios and blossom densities 3 years after the soil drench and several had higher ratios after foliar sprays. Chemical name used: $B-[(4-c h l o r o p h e n y l) m e t h y l\} \alpha-\mid(1, l-d i m e t h y-$ lethyl)-l-H-1,2,4-triazole-l-ethanol (paclobutrazol, PB).

Manipulation of vegetative and reproductive characteristics of apple trees can ensure regular cropping and reduce production costs. These characteristics may be modified by various physical means or by the application of chemicals, such as paclobutrazol (PB). Foliar and soil applications of PB can provide multi-year reductions in shoot growth (Stinchcombe et al., 1984; Tukey, 1983; Williams, 1984) and may also influence assimilate movement and source-sink relationships (Steffens and Wang, 1984; Wang et al., 1985).

Changes in shoot growth and movement of assimilates could modify tree form and fruiting capacity. Choice of apple tree scion

Received for publication 30 May 1989. Paper no. 12218 of the Journal Series of the North Carolina Agricultural Research Service, Raleigh, NC 27695. 7643. The use of trade names in this publication does not imply endorsement by the NCARS of the products named, nor criticism- of similar ones not mentioned. The cost of publishing this paper was defrayed in part by the payment of page charges. Under postal regulations, this paper therefore must be hereby marked advertisement solely to indicate this fact.

'Current address: Box 309, Pennsylvania State Univ. Fruit Research Laboratory, Biglerville, PA 17307. and rootstock may also affect tree architecture and precocity. Our study examined flowering and dry-weight distribution of young apple trees in the 3rd year after planting and PB application. Scion/rootstock combinations (stions) were selected to represent a wide range in scion spur-formation potential and rootstock vigor.

The four stions used in this study were: 'Classic Delicious'/ Malus domestica Borkh. (seedling), 'Classic Delicious'/M.26, 'Redchief Delicious' (Campbell strain)/seedling, and 'Redchief Delicious' (Campbell strain)/ M.26. 'Redchief Delicious' usually develops a more-compact tree canopy, forms more spurs per limb, and is generally more precocious than 'Classic Delicious'. The clonal rootstock M.26 dwarfs scion growth $50 \%$ to $60 \%$ and confers more precocity on a given scion than does seedling.

In Spring 1986, dormant 1-year-old, unbranched trees were planted in 1 vermiculite : 1 montmorillonite clay : 2 pine bark (by volume) in 57-liter pots. Because of space limitations, one tree of each rootstock was planted in each pot. Trees in each pot had either 'Classic Delicious' or 'Redchief Delicious' as the scion cultivar. All trees were planted with the graft union $5 \mathrm{~cm}$ above the soil line. Immediately after planting, trees 
Table 1. Number of blossom clusters per meter of 'Delicious' stion shoot length in Spring 1988.

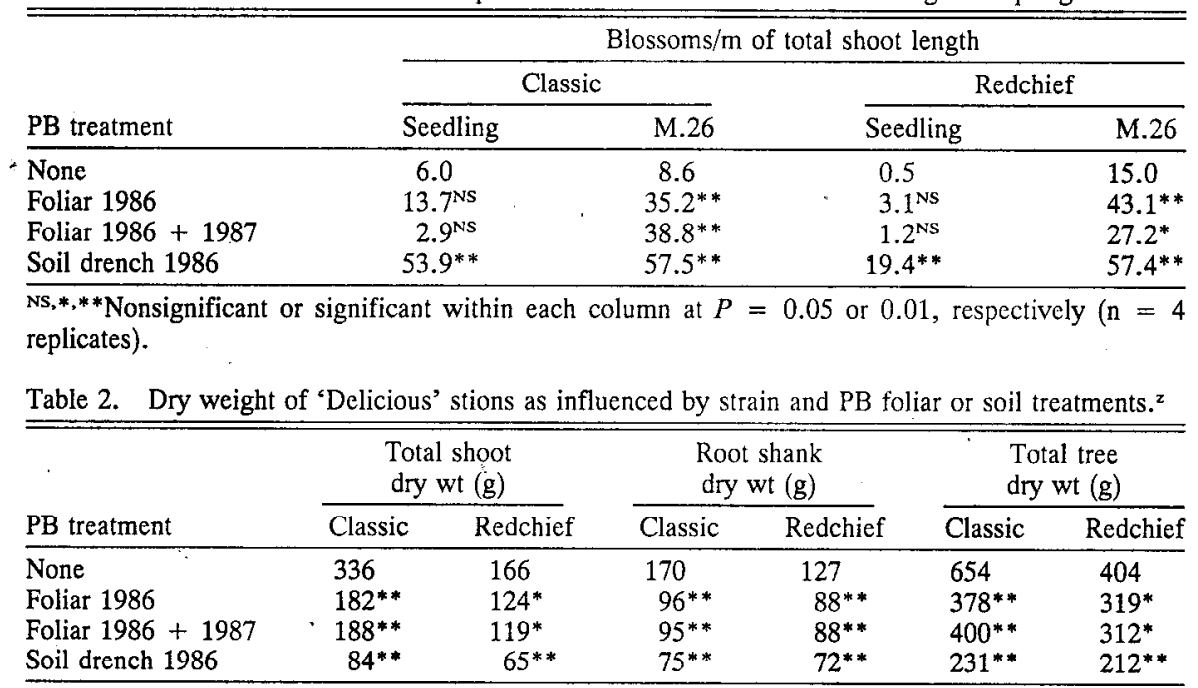

${ }^{2}$ Trees harvested on 30 Aug. 1988.

NS,*** Nonsignificant or significant within each column at $P=0.05$ or 0.01 , respectively $(\mathrm{n}=8$ replicates).

Table 3. Dry weight of 'Delicious' stions as influenced by rootstock and PB foliar or soil treatments. ${ }^{z}$

\begin{tabular}{|c|c|c|c|c|c|c|}
\hline \multirow[b]{2}{*}{$\mathrm{PB}$ treatment } & \multicolumn{2}{|c|}{$\begin{array}{l}\text { Total shoot } \\
\text { dry wt }(\mathrm{g})\end{array}$} & \multicolumn{2}{|c|}{$\begin{array}{l}\text { Total root } \\
\text { dry wt }(\mathrm{g})\end{array}$} & \multicolumn{2}{|c|}{$\begin{array}{l}\text { Total tree } \\
\text { dry wt }(\mathrm{g})\end{array}$} \\
\hline & Seedling & M.26 & Seedling & M.26 & Seedling & M.26 \\
\hline None & 226 & 277 & 276 & 279 & 502 & 556 \\
\hline Foliar 1986 & $159^{*}$ & $146^{*}$ & $229^{N S}$ & $163^{* *}$ & $388^{*}$ & $309 * *$ \\
\hline Foliar $1986+1987$ & $192^{\text {NS }}$ & $115^{* *}$ & $.256^{\mathrm{NS}}$ & $149^{* * *}$ & $448^{\mathrm{NS}}$ & $264^{* *}$ \\
\hline Soil drench 1986 & $66^{* \bar{*}}$ & $84^{* *}$ & $143^{* *}$ & $151^{* *}$ & $208^{* *}$ & $235^{* *}$ \\
\hline
\end{tabular}

Trees harvested on 30 Aug. 1988.

Ns,*,**Nonsignificant or significant within each column at $P=0.05$ or 0.01 , respectively $(\mathrm{n}=8$ replicates).

Table 4. Fibrous root dry weight and root : shoot ratio of 'Delicious' stions as influenced by PB foliar and soil treatments. ${ }^{2}$

\begin{tabular}{|c|c|c|c|c|c|c|c|c|}
\hline \multirow{3}{*}{ PB treatment } & \multicolumn{4}{|c|}{ Fibrous root dry wt (g) } & \multicolumn{4}{|c|}{ Root : shoot ratio } \\
\hline & \multicolumn{2}{|c|}{ Classic } & \multicolumn{2}{|c|}{ Redchief } & \multicolumn{2}{|c|}{ Classic } & \multicolumn{2}{|c|}{ Redchief } \\
\hline & Seedling & M.26 & Seedling & M.26 & Seedling & M.26 & Seedling & M.26 \\
\hline None & 195 & 101 & 117 & 102 & 1.15 & 0.90 & 1.80 & 1.51 \\
\hline Foliar 1986 & $131^{* *}$ & $70^{\mathrm{NS}}$ & $158^{\mathrm{NS}}$ & $56^{*}$ & $1.48^{\mathrm{NS}}$ & $1.19^{\mathrm{NS}}$ & $1.97^{\mathrm{NS}}$ & $1.88^{*}$ \\
\hline Foliar $1986+1987$ & $179^{\mathrm{NS}}$ & $55^{*}$ & $155^{\mathrm{NS}}$ & $55^{*}$ & $1.26^{\mathrm{NS}}$ & $1.50^{* *}$ & $2.25^{*}$ & $1.69^{\mathrm{NS}}$ \\
\hline Soil drench 1986 & $84^{* *}$ & $61^{\mathrm{NS}}$ & $87^{\mathrm{NS}}$ & $63^{* *}$ & $2.50^{* *}$ & $1.91^{* *}$ & $2.68^{* *}$ & $2.64^{* *}$ \\
\hline
\end{tabular}

zTrees harvested on 30 Aug. 1988.

Ns,***Nonsignificant or significant within each column at $P=0.05$ or 0.01 , respectively $(\mathrm{n}=4$ replicates)

were headed-at $70 \mathrm{~cm}$ and disbudded, except for the top two buds. No additional shoot or root pruning was performed. Trees were kept outside for the duration of the study and received fertilization and pest control applications as needed. All trees were deflowered each year to prevent fruit set.

A $4 \times 2 \times 2$ split-split-plot factorial treatment arrangement was used, with four PB treatments as the main plots, two scion cultivars as subplots, and two rootstocks as sub-subplots. All treatments were replicated four times in a randomized complete-block design. Three separate sets of trees were prepared for destructive harvests, using a total of 192 trees.

PB treatments consisted of an untreated control, foliar sprays in the 1st year, foliar sprays in the 1st and 2nd years, and a single soil drench in the 1st year only. Yearly foliar sprays comprised five applications of $\mathrm{PB}$ at $200 \mathrm{mg} \cdot$ liter $^{-1}$ (Cultar 2SC, ICI Americas, Greensboro, N.C.) plus $0.1 \%(\mathrm{v} / \mathrm{v})$ Tween20 surfactant (31.4 mg PB/0.8 liter per year) sprayed biweekly with a backpack sprayer, beginning when untreated trees had at least $8 \mathrm{~cm}$ of new growth. The single soil drench (426 mg PB/0.47 liter per pot) was made on the same day as the first foliar spray in 1986 .

In spring of the 3rd year after planting, total shoot length accrued over 2 years and number of flower clusters per tree were recorded. Blossom density was calculated as the number of blossom clusters per tree per meter of total shoot length.

Destructive harvests were made on 13 Mar 1987 (dormant season 1 year after planting), 7 Mar. 1988 (dormant season 2 years after planting), and 30 Aug. 1988 (active growth $\approx 2.5$ years after planting). At harvest, tree roots were flushed with water to separate the potting mix from the root system. Weights of fibrous roots, root shank, and shoot portions corresponding to each year of growth were measured after drying them at $50 \mathrm{C}$ in a forced-air oven to a constant weight. Shoot was defined as that portion of the tree axis above the graft union, and root shank as that portion below the union. Root : shoot ratio was calculated as rootstock divided by scion dry weight.

Analysis of variance was performed using the General Linear Models (GLM) procedure (SAS Institute, 1985) and mean separation was accomplished using the LSMEANS PDIFF option (Freund and Littell, 1981).

Because of the large volume of data generated in this study, only the results of harvest 3 will be discussed.

Because PB is known to reduce vegetative growth, flowering data recorded 2 years after planting were adjusted for the amount of shoot growth on each tree. The soil drench resulted in the highest blossom densities within each stion class (Table 1). For either scion on seedling, foliar sprays had no effect on bloom density, but higher densities were observed after sprays were applied to either scion on M.26. Thus, inherent rootstock precocity seemed to dictate flower density response to foliar sprays, while scion precocity appeared less important. Other researchers have also reported higher blossom densities after PB application. One year after a soil injection, Dejong and Doyle (1984) observed more flower buds per unit shoot length on 'Fantasia' nectarine. Using large 'Richared Delicious'/seedling apple trees, Jones et al. (1988) found an increase in flower cluster density the year after PB applications were made at various times. Dheim and Browning (1988) found that PB sprays decreased apical dominance and increased floral initiation in two pear cultivars by shortening the plastachron (average time between the appearance of successive primordia within a bud).

For each scion, PB foliar or soil application resulted in lower total shoot, root shank, and tree dry weights, although the reductions in dry weight accumulation appeared smaller for 'Redchief' than for 'Classic' (Table 2).

Most treatments suppressed final total shoot dry weight of both scions on each rootstock, except for repeat sprays applied to scions on seedling, which had no effect (Table 3). In contrast, Blanco (1988) and Tromp (1987) noted enhanced apple tree shoot growth in the year after PB treatment. In our study, trees on M.26 had less total dry weight in root tissue (shank plus fibrous roots) after foliar sprays, but final root dry weight of trees on seedling was not influenced by either foliar spray treatment. Total root dry weight of trees on both rootstocks was lower than that of the control trees after the soil drench. All PB treatments suppressed total tree dry weight for trees on M.26, while only the 2year foliar applications did not affect final tree dry weight for trees on seedlng.

Fibrous root growth of 'Classic'/seedling was suppressed by 1986 foliar sprays or a 
oil drench, while 'Classic'/M.26 trees showed no effect (Table 4). PB treatment did not influence fibrous root dry weight of 'Redchief'/seedling, but the soil drench and the 2-year foliar spray treatments suppressed fibrous root dry weight of 'Redchief'/M.26. El Hodairi et al. (1988) found that root dry weight of 12-week-old 'Delicious' seedlings was not affected by foliar sprays of $500 \mathrm{mg}$ $\mathrm{PB} /$ liter, but root : shoot ratio was higher 28 days after application. In our study, fibrous shoots of all stions that received a soil drench were shorter and thicker than the roots of untreated trees.

Foliar spray treatments did not affect root : shoot ratio of the most vigorous stion, 'Classic'/seedling, but higher ratios were observed for the two intermediate-vigor stions after repeat sprays in 1987 (Table 4). The soil drench more than doubled the root : shoot ratio of 'Classic' on either rootstock, while increases for 'Redchief' on either rootstock were smaller. Early and Martin (1988) reported higher peach seedling root : shoot ratios 3 weeks after adding $0.34 \mu \mathrm{M}$ PB to a nutrient solution culture. Wang et al. (1985) noted a shift in assimilate partitioning from leaf tissue to roots of PB-treated 'York Imperial' apple seedlings growing in nutrient solution culture for several weeks.

Changes in both shoot and rootstock dry weights in response to $\mathrm{PB}$ treatments reflect the characteristic coordiriation of growth among apple tree parts. The observed increase in root : shoot ratio indicated that some treatments preferentially reduced growth of the shoot relative to the root. Further studies are needed to more clearly elucidate the control mechanisms of dry weight allocation in apple trees.

\section{Literature Cited}

Blanco, A. 1988. Control of shoot growth of peach and nectarine trees with paclobutrazol. J. Hort. Sci. 63:201-207.

DeJong, T.M. and J.F. Doyle. 1984. Leaf gas exchange and growth responses of mature 'Fantasia' nectarine trees to paclobutrazol. J. Amer. Soc. Hort. Sci. 109:878-882.

Dheim, M.A. and G.A. Browning. 1988. The mechanism of the effect of (2RS,3RS)-paclobutrazol on flower initiation of pear cvs. Doyenne du Cornice and Conference. J. Hort. Sci. 63:393-405.

Early, J.D., Jr., and G.C. Martin. 1988. Sensitivity of peach seedling vegetative growth to paclobutrazol. J. Amer. Soc. Hort. Sci. 113:2327.

El Hodairi, M.H., A.E. Canham, and W.R. Buckley. 1988. The effects of paclobutrazol on growth and the movement of 14C-labelled assimilates in 'Red Delicious' apple seedlings. J. Hort. Sci. 63:575-581.

Freund, R.J. and R.C. Littell. 1981. SAS for linear models:A guide to the ANOVA and GLM procedures, SAS Inst., Cary, N.C.

Jones, K.M., P. Jotic, T:B. Koen, S.B. Longley, and G. Adams. 1988. Restructuring and crop ping large 'Red Delicious' apple trees with paclobutrazol and daminozide. J. Hort. Sci. 63:1925.

SAS Institute, Inc. 1985. SAS user's guide: Statistics, version 5 edition. SAS Inst., Gary, N.C.

Steffens, G.L. and S.Y. Wang. 1984. Physiological changes induced by paclobutrazol (PP333) in apple. Acta Hort. 146:135-142.

Stinchcombe, G.R., E. Copas, R.R. Williams, and G. Arnold. 1984. The effects of paclobutrazol and daminozide on the growth and yield of cider apple trees. J. Hort. Sci. 59:323-327.

Tromp, J. 1987. Growth and flower-bud formation in apple as affected by paclobutrazol, daminozide and tree orientation in combination with various gibberellins. J. Hort. Sci. 62:433440.

Tukey, L.D. 1983. Vegetative control and fruiting of mature apple trees with PP333. Acta Hort. 137:103-109.

Wang, S.Y., J.K. Byun, and G.L. Steffens. 1985. Controlling plant growth via the gibberellin biosynthesis system. II. Biochemical and physiological alterations in apple seedlings. Physiol. Plant. 63:169-175.

Williams, M.W. 1984. Use of bioregulators to control vegetative growth of fruit trees and improve fruiting efficiency. Acta Hort. 146:97104. 